Revista lus et Praxis, Año 24, No 3, 2018, pp. 765 - 800

ISSN 0717 - 2877

Universidad de Talca - Facultad de Ciencias Jurídicas y Sociales

La tutela del arrendatario frente a las turbaciones jurídicas en el arrendamiento de inmuebles

Íñigo de la Maza Gazmuri - Pablo Ulloa Valenzuela

Trabajo recibido el 10 de noviembre de 2016 y aprobado el 29 de mayo de 2017

\title{
La tutela del arrendatario frente a las turbaciones jurídicas en el arrendamiento de inmuebles
}

\author{
Í́̃igo de la Maza Gazmuri* \\ Pablo Ulloa ValenZuela*
}

RESUMEN

La falta de conformidad jurídica es un asunto escasamente estudiado respecto del contrato de arrendamiento en Chile. Una vez que se le presta suficiente atención, se descubre que se encuentra organizado a través de garantías (evicción y vicios) y normas de expiración del contrato. El objetivo de este trabajo consiste en presentar la forma en que ambos -garantías y terminación- se relacionan con la tutela del arrendatario. Confiamos en que, al hacerlo, a la vez mostremos que una tutela tan fragmentaria resulta inadecuada para la protección del arrendatario.

ABSTRACT

Lack of conformity for legal reason is a scarcely studied matter regarding lease contract in Chile. Once we pay enough attention it comes clear that the issue is organized through the discipline of warranties (eviction and vices) and termination of contract. The aim of this work is, on the one hand, presents the way both -warranties and termination get related to the protection of the leasee and, on the other hands, cast some doubts about the adequacy of such a fragmented system of protection. In the end we suggest a conception of breach wide and unitary must be the answer.

Palabras Clave

Arrendamiento, turbaciones jurídicas, incumplimiento, garantías, expiración

KEY WORDS

Lease, legal lack of conformity, breach, warranties, termination

\section{Introducción}

Dispone el número $3^{\circ}$ del artículo 1924 que el arrendador es obligado a "librar al arrendatario de toda turbación o embarazo en el goce de la cosa

\footnotetext{
* Abogado; Doctor en Derecho; Profesor Investigador Facultad de Derecho de la Universidad Diego Portales; Profesor de Derecho Civil; Dirección postal: República 112, Santiago de Chile. Correo electrónico: inigo.delamaza@udp.cl.

** Abogado; Magíster en Derecho Civil Patrimonial, Facultad de Derecho de la Universidad Diego Portales; Dirección postal: República 112, Santiago de Chile. Correo electrónico: pablo.ulloa@mail.udp.cl.
} 
arrendada". En la comprensión de esa norma no se duda de que la turbación puede ser de hecho o de derecho.

Al tratar las turbaciones de derecho, la doctrina nacional ha considerado únicamente el supuesto disciplinado por el artículo 1930, es decir, el correspondiente a la evicción.

Nuestra sugerencia es que esa es una comprensión restringida de la tutela del arrendatario que obstaculiza una adecuada comprensión del inadecuado régimen de tutela del arrendatario, frente a la presencia de turbaciones jurídicas que disciplina el Título XXVI del Libro IV del Código Civil. Proponemos, en cambio, una comprensión amplia de la idea de turbación jurídica. Una que se endereza en torno a la utilidad de la cosa para el fin que ha sido arrendada.

Aplicando esa noción -que es nada más que un derivado de una concepción amplia y unitaria del incumplimiento contractual- procuramos ofrecer un tratamiento más sistemático del elenco de situaciones en que por razones jurídicas la cosa no es útil para el fin a que ha sido arrendada.

La estructura de este trabajo es la siguiente. En la primera parte (I) presentamos un par de cuestiones preliminares que deben contribuir a mostrar la forma en que pretendemos exponer el estado de las turbaciones de derecho en el ámbito nacional. Al hacerlo, mostramos que el tratamiento de dichas turbaciones se canaliza ya sea a través de la disciplina del saneamiento o bien de la expiración del contrato. La segunda parte (II) presenta el régimen de los saneamientos, distinguiendo según se trate de la evicción o del particular régimen de los vicios redhibitorios en el contrato de arrendamiento. Por último, la tercera parte (III) se refiere al régimen de la expiración del contrato de arrendamiento en la medida que canaliza supuestos de turbaciones jurídicas.

Una prevención antes de comenzar: este trabajo es más de diagnóstico que de cura. Es decir, se preocupa más de evidenciar una situación regulatoria inadecuada que de prescribir cómo debería resolverse. Con todo, alguna sugerencia al respecto puede encontrarse en las conclusiones.

\section{Un par de cuestiones preliminares}

\section{Turbaciones de derecho, una concepción restringida y una amplia}

\section{a. Una concepción restringida}

Habrá que comenzar advirtiendo que el contrato de arrendamiento no ha sido el hijo favorito de la doctrina en el ámbito nacional. Las obras monográficas son escasas y no particularmente ambiciosas. El tema que ocupa a este trabajo parece ilustrar la situación de manera conspicua.

Así, por ejemplo, si se presta atención a los manuales, al tratar lo referente a las turbaciones de derecho Meza Barros señala: 
"Turbación de derecho es aquella que se produce por vías de derecho, esto es, por las acciones que terceros entablen alegando derechos sobre la cosa arrendada"1.

$Y$, más adelante, detalla que:

"De tales turbaciones es responsable el arrendador porque, en verdad, provienen de una mala calidad de su derecho.

Como el derecho del arrendador queda en tela de juicio, él debe intervenir; el arrendatario no tiene calidad para representarle en el debate en que se discuta el derecho del arrendador" ${ }^{\prime 2}$.

En el mismo sentido Vodanovic, sobre las turbaciones de Derecho, las identifica como aquellas en las cuales "el tercero pretenda un derecho sobre la cosa" en términos tales que:

"cuando la pretensión del tercero es de derecho (pretende ser dueño o acreedor hipotecario o se cree con derecho a una servidumbre), entonces sí que responde el arrendador" ${ }^{3}$.

Por su parte, Barcia Lehman limita la cuestión al siguiente párrafo:

"La turbación de derecho es la que se produce por la acción que un tercero entabla alegando tener un derecho sobre la cosa arrendada, es decir, debe ser generada por una acción judicial. A su vez, el arrendatario está obligado a notificar la turbación al arrendador" ${ }^{\prime 4}$.

Por lo que toca a obras de carácter más monográfico, Ducci Claro se refiere a las provenientes de haberse arrendado una cosa ajena y al artículo $1930^{5}$. Orrego Acuña indica como obligación del arrendador la de amparar al arrendatario en las turbaciones de derecho a través de un breve análisis de los cuatro últimos incisos del artículo $1930^{6}$. Por su parte, Cornejo Aguilera limita su análisis a la siguiente situación:

"...el caso de las turbaciones de derecho que provengan de terceros, que pretenden derechos sobre la cosa cuya causa sea anterior al contrato de arrendamiento, y que resulten incompatibles con los derechos

\footnotetext{
1 MeZa (2007), p. 102.

2 MeZa (2007), p. 103.

3 VODANOVIC (1942), p. 458.

4 Barcia (2007), p. 133.

5 DucCl (1982), p. 48.

${ }^{6}$ Orrego (2011), pp. 180-181.
} 
surgidos del contrato celebrado, caso en el cual cobra pleno vigor la obligación de saneamiento" ${ }^{\prime 7}$.

Haciendo pie en estos autores, el concepto de "turbaciones de derecho" pareciera limitarse al supuesto considerado en los incisos segundo y siguientes del artículo 1930. Y esta es la que denominamos una concepción restringida de las turbaciones de derecho.

Ahora bien, esto no debe entenderse como una crítica a los autores que hemos citado, pues, muy probablemente, considerando la forma en que el Título XXVI del Libro IV sistematiza la regulación del contrato de arrendamiento, resulte acertada. Sin embargo, nuestra opinión es que, precisamente, es esa sistematización la que oscurece el panorama pues modula de forma inadecuada la tutela del acreedor frente a situaciones jurídicas que turban el goce de la cosa a que tiene derecho según el contrato.

\section{b. Una concepción amplia}

Creemos que resulta posible presentar las cosas con más claridad. Para estos efectos podemos comenzar considerando que, desde la perspectiva del arrendatario, lo relevante parece ser que aquello que se le entregue resulte útil para el fin a que ha sido arrendado. Este lenguaje -"el fin a que ha sido arrendada" - se emplea en el número $2^{\circ}$ del artículo 1924 para aludir a la obligación del arrendador de mantener la cosa, sin embargo, creemos que se puede utilizar de forma más general para capturar una idea más amplia, y es aquella según la cual existe un "propósito práctico" en los contratos que corresponde a la finalidad de las partes que el Derecho protege ${ }^{8}$. Como ha de resultar evidente, en contratos como el arrendamiento en los cuales la prestación de una de las partes exige la entrega de una cosa, la satisfacción del propósito práctico va a depender, en parte al menos, de que la cosa se adecue material y jurídicamente a dicho propósito.

Esta idea, más bien infrecuente en el ámbito nacional respecto del contrato de arrendamiento ${ }^{9}$, ha ganado cierta fortuna respecto de la compraventa, en la cual suele señalarse que la cosa debe adecuarse material y jurídicamente al contrato $^{10}$. Respecto de la conformidad jurídica -que es la que interesa a este trabajo- lo decisivo, como ha señalado Mullis respecto de la Convención

\footnotetext{
7 Cornejo (2012), p. 194.

${ }^{8}$ VIDAL (2009), pp. 246-247; Galván (1998), p. 15, y sobre la idea de propósito práctico ver De CASTRO (1997), § 33 y MORAles (2006), pp. 323-348.

9 De la Maza (2009), p. 252; Orrego (2011), pp. 182-183, y Musalem (2015), p. 23.

10 Aburto y De la Maza (2015); De la Maza (2015).
} 
de las Naciones Unidas sobre Compraventa Internacional de Mercadería (CISG) es si, por así decirlo, que la situación jurídica del bien impide que el vendedor pueda gozar pacíficamente de la cosa y utilizarla, revenderla o disponer de otra manera de la cosa ${ }^{11}$. Mutatis mutandis lo mismo puede afirmarse en el contrato de arrendamiento, lo relevante debe ser si la situación jurídica del bien impide que el arrendatario se sirva de ella para el fin a que ha sido arrendada.

Esta idea de Mullis nos permite pensar en una concepción amplia de las turbaciones de derecho referidas a cualquier situación de carácter jurídico que impida el uso para el cual la cosa fue arrendada.

Ahora bien, el sistema de tutela del comprador de la CISG es suficientemente distinto del de la compraventa del Código Civil y más aún del propio del contrato de arrendamiento, de manera que es necesaria alguna cautela. No pretendemos afirmar que el régimen de tutela del arrendatario en el Código Civil se asemeja a la CISG, sino que, cuestión distinta, pensamos que considerar una idea amplia de conformidad jurídica permite formular una noción más amplia de turbaciones de derecho que, a su vez, nos permite calibrar con mayor precisión la tutela del arrendatario cuando la situación jurídica de la cosa impide que el arrendatario se sirva de ella para el fin a que ha sido arrendada.

Nuestra noción amplia de turbaciones de derecho, equivale a aquellas circunstancias que determina que la situación jurídica del bien impida u obstaculice que el bien sirva al fin a que ha sido arrendado.

\section{Un mapa de las turbaciones de derecho}

La utilidad de esta noción amplia es simplemente la de unos anteojos: permite mirar las cosas con más claridad. La pregunta ha de ser ¿de qué manera puede verse turbado jurídicamente el arrendatario en su goce de la cosa?

\section{a. Derechos de terceros}

Como ya lo hemos afirmado, la doctrina nacional ha limitado el tratamiento de la cuestión a la presencia de derechos de terceros cuya causa sea anterior al contrato de arrendamiento. En el Código Civil esta situación es tratada por el artículo 1930 y, según se verá, corresponde al tratamiento de la evicción a propósito de dicho contrato.

Sin embargo, aun si se limita la cuestión a derechos de terceros, es posible considerar otras situaciones que pueden perturbar jurídicamente el goce del

11 Muluis (2007), p. 170. 
arrendatario. Para advertirlo, es necesario tener en cuenta que la disciplina de la evicción exige, en primer lugar, que la causa del derecho sea anterior al contrato de arrendamiento. En segundo lugar, la tutela que prodiga el régimen de la evicción al arrendatario tiene lugar cuando éste ha sido privado de la cosa o de una parte de ella.

Al considerar las cosas de esta manera, surgen dos preguntas. La primera de ellas es qué sucede cuando existen derechos de terceros pero estos son sobrevinientes, es decir, han surgido con posterioridad al perfeccionamiento del contrato de arrendamiento. La segunda pregunta -tratándose de derechos cuya causa sea anterior al contrato- es, qué sucede si existen esos derechos, pero el arrendatario no ha sido privado de la cosa arrendada o de una parte de ella. En estos dos casos la pregunta es la siguiente ¿dispone el arrendatario de algún tipo de tutela?

\section{b. Expropiación y embargo}

Ahora bien, la existencia de derechos de terceros sobre la cosa puede no ser la única circunstancia que tenga aptitud para obstaculizar jurídicamente el goce del arrendatario sobre la cosa. Al menos dos situaciones especiales, que se asemejan a aquella de los derechos de tercero, merecen consideración. La primera de ellas tiene lugar cuando la cosa es expropiada. La segunda situación se presenta cuando los acreedores del arrendador traban embargo sobre la cosa arrendada. Una vez más, la pregunta es la misma ¿dispone el arrendatario de algún tipo de tutela?

\section{c. Vicios jurídicos}

Resta considerar una situación diversa de las anteriores. Se trata de aquellos supuestos en los que, por así decirlo, existe un "vicio jurídico" que impide que la cosa sirva al uso a que ha sido arrendada. Sobre este supuesto necesitamos advertir que empleamos la expresión "vicio" pues la forma en que lo han considerado los tribunales es la propia del tratamiento de los vicios en el contrato de arrendamiento.

Estas, según nos parece, son las turbaciones de derecho que puede experimentar un arrendatario y lo que ahora resta consiste en determinar con mayor precisión la fisonomía de esas perturbaciones.

\section{d. Un tratamiento fragmentario}

Si se consideran las situaciones recién aludidas a la luz del Título XXVI del Libro IV del Código Civil y se tiene presente que la obligación del arrendador a este respecto es liberar al arrendatario de toda turbación, entonces aparece 
que el tratamiento que prodiga el Código Civil a la cuestión es extraordinariamente fragmentario.

En primer lugar, tratándose de los derechos de terceros cuya causa es anterior al contrato, no nos encontramos, propiamente, frente a una obligación, sino a una garantía: la de saneamiento por evicción ${ }^{12}$.

En segundo lugar, por lo que toca a la presencia de derechos de terceros sin que haya evicción, el Código parece no haberlo considerado.

En tercer lugar, tratándose del embargo y de los derechos de terceros sobrevenidos, el Código Civil los trata a propósito de la expiración del contrato de arrendamiento.

En cuarto lugar, tratándose de los vicios jurídicos, es una garantía, pero esta vez por vicios redhibitorios.

Y la pregunta que surge de manera más bien espontánea es ¿por qué, si en definitiva se trata de incumplimientos de la obligación del arrendador, ha de tratarse a través de regímenes jurídicos diversos? ¿No resultaría más sencillo disponer de una noción amplia y unitaria de incumplimiento que los agrupara a todos bajo un mismo régimen de remedios?

No obstante lo anterior, en lo que queda de este trabajo, presentaremos el régimen de tutela del acreedor de la manera fragmentada en que lo hace el Código, más que nada con la finalidad de mostrar que no obstante los regímenes de tutela diversos, el supuesto que los activa es el mismo: la existencia de una turbación jurídica.

De esta manera, en primer lugar, en el apartado siguiente (II) consideramos los saneamientos y luego, en el último apartado (III), prestaremos atención a la expiración del contrato. A propósito de la expiración del contrato, consideraremos, únicamente, el caso que nos parece más desafiante, que son los derechos sobrevinientes de terceros sobre la cosa. Quedará, entonces, para otro trabajo, considerar la expropiación y la situación del embargo.

\section{Los saneamientos}

Señala Díez-Picazo que en la Instituta de Gayo existe un texto según el cual "el arrendamiento es figura muy próxima a la compraventa y está sometido a las mismas reglas"13. Al menos una cosa es cierta, tanto en la compraventa como en el arrendamiento existe la obligación de entrega y la de saneamiento. Tratándose de la regulación del Código Civil chileno, el saneamiento de la evicción se encuentra disciplinada en el artículo 1930 y el de los vicios en los

\footnotetext{
12 Ver Carrasco (2010), p. 1319.

13 Díez-Picazo (2010), p. 257.
} 
artículos 1932 a 1937. Se trata, como veremos, de dos regímenes de garantía, cuyos orígenes se encuentran en el derecho romano ${ }^{14}$.

\section{La evicción}

La evicción es, desde el derecho romano, un régimen que mezcla la garantía y la responsabilidad. Frente a la privación parcial o total de la goce el arrendatario, según corresponda, tiene derecho ex artículo 1930 a que se disminuya la renta o a que cese el arrendamiento. A este respecto la buena o mala fe del arrendador es irrelevante; esa es la garantía que se ha mantenido así desde el derecho romano ${ }^{15}$. La falta del arrendador únicamente es relevante para efectos indemnizatorios.

Pues bien, la pregunta que nos interesa ahora es precisar la situación de estos derechos de terceros a que alude el artículo 1930 y que ocasiona la turbación de derecho.

Desgraciadamente ni la doctrina nacional ni los tribunales han prestado demasiada atención al asunto. La doctrina se ha limitado a indicar que se trata de derechos de terceros cuya causa es anterior al contrato ${ }^{16}$. Por otra parte, hasta donde llegan nuestras noticias, la aplicación que han hecho los tribunales de este precepto resulta escasa y no se refiere al tema que nos ocupa ${ }^{17}$. La historia del precepto, sin embargo, puede ser de alguna utilidad. Como resulta suficientemente sabido. En el proyecto de 1853 consta la siguiente nota para el artículo 2109 (actual 1930):

"Art. 2109, inc. $5^{\circ}$ Se han seguido, con algunas modificaciones, la lei 21, tit. 8, P. 5; i la doctrina de Pothier, desde el núm. 82 al 105".

De esta manera, Bello deja indubitada constancia de las fuentes que se tuvo a la vista para la redacción del artículo en comento: las Siete Partidas y Pothier ${ }^{18}$.

\footnotetext{
14 Ver ZimMERMANN (1992), pp. 362-369.

15 Ver ZimMERMANN (1992), p. 363.

16 Meza (2007), p. 103; Ducci (1982), p. 48; Orrego (2011), p. 180, y Cornejo (2012), p. 194.

17 A modo de ejemplo, las sentencias tratan del 1930. Como norma que regula la parte no expropiada de un predio, Corte Suprema, rol № 2585-2008, de 28 de diciembre de 2009; como el artículo en el cual se encuentra regulada la obligación de mantener la cosa en estado de servir para el fin a que ha sido arrendada, y librar al arrendatario de toda turbación o embarazo en el goce de la cosa arrendada, Corte Suprema, rol No 10766-2013, de 17 de marzo de 2014.

18 Si bien la nota está hecha con vínculo al inc. $5^{\circ}$ del 2109 , creemos que es aplicable desde el inc. $2^{\circ}$ en adelante; lo anterior, toda vez que, en primer lugar,la lectura de las fuentes nos muestra la correspondencia que hay entre lo regulado, de una parte, por Las Siete Partidas Ley 21, tit. 8, P. 5, y, de otra, por Pothier (1841), $N^{\circ}$ s. 82 al 105 y por el artículo 2109 Incisos $2^{\circ}, 3^{\circ}, 4^{\circ}$ y $5^{\circ}$; y, en segundo lugar,que el "referido derecho" señalado en el Inc. $5^{\circ}$ de la norma, se entiende sólo en la medida de los incs.
} 
Considerando "Cuáles son las perturbaciones por las cuales debe el locador estar de evicción", Pothier se refiere a la "perturbación judicial" en los siguientes términos:

"Ella es procedente de una demanda puesta por alguno contra dicho arrendatario para que le deje vacía y expedita la heredad o una parte de ella de la cual se pretende dueño ó usufructuario el actor; o bien para que se obligue al arrendatario a que permita el ejercicio de alguna servidumbre que el demandante pretende tener sobre la heredad arrendada, y de que no se hizo cargo el arrendatario al tornarla en arrendamiento. También puede proceder de excepciones que contengan pretensiones análogas, puestas a la demanda que hubiese entablado el arrendatario, para que se le mandase abstener de perturbarlo en su goce. Estas perturbaciones judiciales pueden Ilamarse evicciones, no ya de la cosa sino del goce de la misma"19.

De esta manera, debiéramos entender que esas perturbaciones tienen lugar cuando existe un tercero con derechos que obstaculizan el goce del arrendatario. Este tercero demanda en ejercicio de esos derechos y, en definitiva, se priva total o parcialmente del goce de la cosa al arrendatario. Se trata en trazos gruesos de un sistema extremadamente semejante al de Las Siete Partidas en la Ley 21, tit. 8, P. $5^{20}$. Así, por ejemplo, podrá tratarse del derecho de dominio en el caso de arrendamiento de cosa ajena ${ }^{21}$ u otros derecho reales como las servidumbres o el usufructo tal como lo indica Pothier o de una hipoteca. Una mirada al régimen de la evicción en el contrato de compraventa indica que también podría tratarse de acciones posesorias ${ }^{22}$.

$2^{\circ}, 3^{\circ}$, y $4^{\circ}$, de guisa que, la nota hecha al inc. $5^{\circ}$ del artículo 2109 , en cuanto a sus antecedentes, impregna todo el artículo en comento.

19 POthier (1841), p. 47

20 Ley 21, tit. 8, P. 5: "Tienen arrendandas los homes unos de otros heredades, ó viñas, ó huertas ó otras cosas semejantes, et toman otrosi á loguero casas, ó torres ó otros edificios, et acaesce á las veces que resciben embargo de guisa que non pueden usar nin aprovecharse dellas et por ende decimos que si los señores destas cosas sobredichas ó otros á quien lo ellos podiesen vedar, embargasen en alguna manera á los que las toviesen arrendadas ó logadas que non podiesen usar nin aprovecharse dellas, que les deben pechar los daños et los menoscabos que les viniesen por tal razon como esta, et aun débenles pechar demas desto las ganancias que podieran haber fecho en aquellas cosas que tienen arrendadas ó logadas, si gelas non hobiesen ellos ambargado. (...)".

21 Ver artículo 1916 inc. $2^{\circ}$ del Código Civil.

${ }^{22}$ Ver Corte de Apelaciones de Santiago, no registra rol, de 31 de agosto de 1949. 
Ésta, como ya se ha visto, es la turbación jurídica que ha llamado la atención a la doctrina nacional. Sin embargo, también se ha dicho. No es la única. Convendrá considerar otras semejantes.

Una primera posibilidad que puede plantearse es la del doble arrendamiento disciplinada por el artículo $1922^{23}$. Sin embargo, resulta necesario advertir que para que esta situación tuviera lugar, tendría que ser el caso que se hubiera entregado la cosa a los dos arrendatarios y, siendo de esta manera, el artículo 1922 dispone que la segunda entrega no vale, por lo mismo, la tutela del arrendatario encontraría su acomodo no en la evicción, sino en los remedios propios de la falta de entrega.

Una segunda posibilidad se refiere a situaciones en que si bien existen derechos de terceros, estos no han demandado.

A esta segunda posibilidad se refiere el artículo IV.B-3:101 (3) de los Principles of European Law Lease of Goods (PEL LG) ${ }^{24}$ dispone que:

"Los bienes deben permanecer disponibles para su uso por el arrendatario durante todo el plazo del arrendamiento, libres de cualquier derecho o reclamación de terceros que impidan o interfieran en el uso de los bienes por el arrendatario de acuerdo con los términos contractuales".

En el Comentario G del artículo IV.B-3:101, se señala que el arrendatario no debe esperar a ser privado de la cosa arrendada, en la medida en que los derechos o reclamaciones de terceros amenacen su goce dispone de los remedios propios del incumplimiento contractual ${ }^{25}$.

Bajo ciertas circunstancias, entonces, basta la presencia de derecho de terceros, aunque no exista evicción. Como ha de resultar evidente, en el ámbito nacional, esta situación no queda cubierta por la disciplina del artículo $1930^{26}$. Sin embargo, el Código trata un supuesto, a propósito de la expiración del contrato de arrendamiento, el embargo, sobre el cual volveremos más adelante.

La tercera posibilidad que consideramos aquí se refiere a los derechos sobrevinientes de terceros.

Refiriéndose a las reglas que deben orientar el tratamiento de la evicción Pothier señala que:

\footnotetext{
23 Ver, por ejemplo Cámara (2008), p. 359.

24 LILLEHOLT et al. (2008).

25 Lilleholt et al. (2008), p. 159.

26 Para que opere la disciplina de la evicción en el arrendamiento ha de ser el caso que se satisfagan copulativamente tres requisitos, a saber: (1) la privación total o parcial de la cosa, (2) por sentencia judicial, y (3) en virtud de un derecho anterior al arrendamiento.
} 
"Cuando la causa de la evicción no existió hasta después del arrendamiento, deberá el locador responder de ella, si procede de hecho suyo propio; del contrario no debería responder.

El caso de la primera parte de esta regla se verifica cuando después de celebrado el arrendamiento el locador vendió sin necesidad alguna, o enajenó por cualquier otro título la heredad arrendada, sin encargar al comprador que cumpliese con el arrendamiento o cuando después de la celebración de este concedió a la heredad vecina un derecho de servidumbre.

Aun cuando la venta fuese forzada y hecha a consecuencia de una instancia ejecutiva puesta por los acreedores del locador, debería estar de evicción al conductor que se vería privado del goce de la heredad por el adjudicatario; puesto que aun entonces sucedería esto por hecho del locador, que hechos suyos son las deudas que él tiene que pagar, y por las cuales se vende la heredad.

Para ejemplo del segundo caso de la regla supongamos que después de haberme Juan dado a alquiler su casa, la municipalidad obtuvo autorización para obligarle a venderla por el precio en que se estimase, para destruirla y levantar en su lugar un edificio público. Hecha la valoración y satisfecho el precio, la municipalidad me manda que desocupe la casa; ¿deberá Juan estarme de evicción? No; porque el derecho que tiene el concejo municipal para privarme del goce de la casa no empezó hasta después de celebrado el arriendo, y no es procedente de hecho del locador el cual no pudo oponerse a la enajenación prescrita por causa de utilidad pública. Solo deberá absolvérseme del pago de los alquileres desde el día en que tuve que desocupar la casa" 27.

En el Código Civil, sin embargo, las cosas son distintas. Como veremos, la pérdida del derecho del arrendador $-\mathrm{y}$, por lo tanto, el surgimiento del derecho de un tercero- no es tratado como causa de evicción, sino como causal de expiración del contrato. El caso de la segunda parte de la regla se asemeja al del artículo 1960, que también constituye una causa de expiración.

Una cuarta posibilidad que hemos de considerar corresponde a otras perturbaciones jurídicas, esta vez no referidas a privación total o parcial de la cosa, sino más bien a vicios de la cosa: ¿quedan cubiertos por el régimen de la evicción del artículo 1930?

27 Pothier (1841), p. 49. 
La pregunta resulta interesante pues, tratándose de la evicción en la compraventa, Alessandri Rodríguez señala como causal de evicción parcial: "Cuando el comprador se ve obligado a pagar una deuda que pesa sobre el predio vendido para no ser molestado en su posesión y dominio tales como réditos, censos, hipotecas, etc. ${ }^{\prime 28}$. Por otra parte -siempre tratándose de la compraventa- los tribunales han aplicado el régimen de la evicción frente a la existencia de cargas y limitaciones administrativas ${ }^{29}$.

Una mirada a las decisiones de los tribunales superiores de justicia parece mostrar que, tratándose del contrato de arrendamiento, este tipo de situaciones no se canaliza a través de la disciplina de la evicción, sino a propósito de la de los vicios tratada entre los artículos 1932 y 1937 del Código Civil.

Pues bien, como se ve, el régimen de la evicción, al que la doctrina suele limitar las turbaciones de derecho, es más bien modesto respecto a las situaciones en las que dispensa algún tipo de tutela al arrendatario; se limita a situaciones en las que existe un derecho cuya causa es anterior al contrato y que, ejercido por su titular, priva al arrendatario de todo o parte de la cosa arrendada.

Con respecto a los Medios de tutela que prodiga el régimen de la evicción al arrendatario, la doctrina nacional no se ha ocupado mayormente de la cuestión ${ }^{30}$. Como sucede en la compraventa, el régimen de la evicción combina garantía y responsabilidad. Así se dispone en el artículo 1930. La garantía se manifiesta en la disminución proporcional del precio o en el cese del arrendamiento según corresponda. Por su parte, la responsabilidad se traduce en una indemnización que se debe en aquellos casos en los cuales el arrendador conocía o debió conocer la causa del derecho anterior y el arrendatario la ignoraba. Igualmente se debe si ha existido una estipulación especial de saneamiento.

\section{Los vicios jurídicos como vicios redhibitorios}

En este apartado nos interesa examinar los vicios jurídicos de la cosa como supuestos de turbación jurídica.

A diferencia de lo que sucedía con la evicción, aquí sí que encontramos sentencias que deben contribuir a ilustrar la cuestión. Convendrá considerar algunos de estos $\operatorname{casos}^{31}$.

\footnotetext{
28 Alessandri (2003), p. 51.

${ }^{29}$ Ver, por ejemplo, sentencia de Corte de Apelaciones de Santiago, no registra rol, de 31 de diciembre de 1982.

30 Alguna información en CORNejO (2012), pp. 195-196.

31 Hemos tomado estos ejemplos de la tesis de Magíster de doña Francisca Musalem. Musalem (2015).
} 
El primero de ellos corresponde a un caso fallado por la Corte de Apelaciones de Antofagasta con fecha 27 de marzo de $2003^{32}$. Se trató del arrendamiento de un inmueble que se destinaría al almacenaje y venta de productos. Sin embargo, por limitaciones del plan regulador no resultaba posible asignarle ese destino.

El segundo caso es uno fallado por la Corte Suprema con fecha 29 de septiembre de $2003^{33}$. En los hechos, se trató del arrendamiento de un inmueble que se dedicaría a un jardín infantil. La arrendadora autorizó expresamente a la arrendataria a solicitar a la Municipalidad de Concepción el cambio de destino del inmueble. Sin embargo, el permiso fue denegado toda vez que el inmueble no cumplía con las normas relativas a los permisos ni con las relativas a la recepción de obras.

El tercer ejemplo, corresponde a una conocida sentencia de la Corte de Apelaciones de Santiago de 29 de noviembre de $2007^{34}$, confirmada luego por la Corte Suprema. Se trata del arrendamiento de un predio, especificándose en el contrato que únicamente podría dedicarse a instalar y operar un campo de minigolf. Se estableció que la arrendataria tramitaría los permisos, sin embargo, al solicitarlos, se encontró con que no era posible asignarle dicho uso pues el predio no estaba urbanizado, no contaba con permiso de edificación ni recepción definitiva y, además, el terreno mayor al que pertenecía el predio no respetaba la línea oficial, de manera que nunca obtendría patente ni la recepción final.

El cuarto ejemplo corresponde a una sentencia de la Corte de Apelaciones de Santiago de 6 de enero de 2010 ${ }^{35}$. Esta vez se trató del arrendamiento de un inmueble para dedicarlo a oficinas comerciales. Sin embargo, el uso del suelo establecido por el plan regulador de la comuna impedía asignarle ese destino.

Un quinto ejemplo puede encontrarse en la sentencia de la Corte de Apelaciones de Santiago de 28 de marzo de 2014 ${ }^{36}$. Esta vez, el contrato de arrendamiento tuvo como objeto un inmueble que registraba deudas extraordinariamente cuantiosas por agua potable y por luz eléctrica, por lo cual, ambos servicios se encontraban cortados.

\footnotetext{
32 Corte de Apelaciones de Santiago, rol № 2206-1998, de 27 de marzo de 2003.

${ }^{33}$ Corte Suprema, rol No 4312-2003, de 29 de septiembre de 2003.

${ }^{34}$ Corte de Apelaciones de Santiago, rol No 3073-2003, de 29 de marzo de 2003.

35 Corte de Apelaciones de Santiago, rol № 7153-2008, de 6 de enero de 2010.

${ }^{36}$ Corte de Apelaciones de Santiago, rol No 6564-2013, de 28 de marzo de 2014.
} 
El sexto ejemplo proviene de una sentencia de la Corte Suprema; esta vez de 13 de agosto de $2015^{37}$. Se arrendó un departamento para un uso diverso del que permitía el condominio en el que se encontraba, por lo mismo, el arrendatario no pudo destinar el inmueble al uso que garantizaba el contrato.

Por último, el séptimo caso corresponde a una sentencia de 6 de octubre de $2016^{38}$. Se arrendó un inmueble para dedicarlo a actividades educacionales. Sin embargo, en la recepción definitiva de edificaciones realizadas en el inmueble -anterior al contrato de arrendamiento-, se señalaba que se excluían las actividades de educación.

Como puede advertirse al considerar este conjunto de casos el problema que se presenta en todos ellos se refiere a un cierto obstáculo -distinto a derechos de terceros en el sentido que lo exige la disciplina de la evicción- que impide al arrendatario asignar el uso de la cosa que el contrato le garantizaba. Lo segundo que se descubre sin mayor dificultad, es que ese obstáculo no es de carácter material; no es que la situación física de la cosa impida el uso, sino más bien, una circunstancia de carácter jurídico que, en todos los casos, resulta diversa de la presencia de derechos de terceros en el sentido en que los considera el artículo 1931.

Ilustrados los supuestos de los vicios jurídicos como turbación de derecho, corresponde ahora advertir que los tribunales los han considerado al abrigo de los artículos 1932 y siguientes, es decir, a propósito de una garantía que parece relacionarse más bien con la obligación del arrendador de entregar la cosa y de mantenerla en estado de servir para los fines que fue arrendada ${ }^{39}$.

Convendrá seguir el mismo orden en que se presentaron los casos anteriormente.

Tratándose del primero -el inmueble que se iba a dedicar a almacenaje- la Corte de Apelaciones de Santiago confirma completamente la sentencia del $15^{\circ}$ Juzgado Civil de Santiago de 27 de enero de 1998 y, haciendo pie en el artículo 1932, establece que la arrendataria tenía derecho a poner término al contrato de arrendamiento ${ }^{40}$. Los considerandos son los siguientes:

“ $12^{\circ}$. Que, de lo examinado se desprende que habiéndose celebrado entre las partes un contrato de arrendamiento para que el inmueble sirviera de almacenaje y venta de productos, en definitiva no sirvió para tal

\footnotetext{
37 Corte Suprema, rol № 7205-2015, de 13 de agosto de 2015.

${ }^{38}$ Corte Suprema, rol No 55067-2016, de 6 de octubre de 2016.

39 Cornejo (2012), pp. 186-187.

${ }^{40}$ Corte de Apelaciones de Antofagasta, rol № 913-1996, de 27 de enero de 1998.
} 
fin, no obstante los esfuerzos hechos por la demandada para obtener de la Ilustre Municipalidad de Santiago las autorizaciones para funcionar.

13․ Que, el artículo 1932 del Código Civil dispone que el arrendatario tiene derecho a la terminación del arrendamiento si el mal estado o la calidad de la cosa le impide hacer de ella el uso para el que ha sido arrendada, sea que el arrendador conociese o no el mal estado o calidad de la cosa al tiempo del contrato y aun cuando el vicio de la cosa se hubiera iniciado después del arrendamiento, pero sin culpa del arrendatario.

14. Que, la Excma. Corte Suprema en fallo de 12 de diciembre de 1941, compulsado bajo el No 3 del repertorio al artículo 1932 del Código Civil, señaló que lo fundamental para el ejercicio de la acción que concede el artículo 1932 del Código Civil es el lecho de ser imposible el uso de la cosa arrendada, cualquiera que sea el motivo o circunstancia que lo produzca, pues la ley sólo excluye la destrucción causada después del contrato, por culpa del arrendatario. Señala el Alto Tribunal que tal interpretación guarda armonía con la estructura del contrato de arrendamiento que es bilateral y de tracto sucesivo, por ello el uso y goce de la cosa arrendada constituye el objeto de las obligaciones que contrae el arrendador y la causa de las obligaciones del arrendatario, que deben ser renovadas constantemente; agrega que, desde el momento que el uso y goce de la cosa no puede ser proporcionado en los términos previstos por los contratantes, al contrato le faltan los elementos necesarios para subsistir jurídicamente, por lo que resulta lógico que el contrato termine y se libere al arrendatario de la obligación de pagar por el uso y goce que no se le proporciona en la forma convenida.

$15^{\circ}$. Que, en el caso que nos preocupa, resulta evidente que el inmueble no cumplía con los requisitos necesarios para ser usado para la finalidad prevista en el contrato, cual fue, la venta y almacenaje de la mercadería de la demandada. Cabe destacar que esta carencia no le es imputable al arrendatario y que, por el contrario, éste intentó por los Medios a su alcance de revertir la decisión municipal, lo que no logró".

En el segundo caso -el del inmueble que se iba a destinar a jardín infantil- la arrendataria solicita al tribunal que declare la resolución del contrato de arrendamiento por no poder destinar el inmueble al uso que aparecía en el contrato. En definitiva, la Corte Suprema invalida la sentencia de la Corte de Apelaciones de Casación y confirma la del $3^{\text {er } J u z g a d o ~ C i v i l ~ d e ~ e s a ~ c i u d a d ~ q u e ~}$ es, entonces, la que interesa. Los considerandos pertinentes son los siguientes: 
"13․ Que de conformidad a lo dispuesto en el artículo 1915 del Código Civil, el arrendamiento es un contrato en que dos partes se obligan recíprocamente, la una a conceder el goce de una cosa y la otra a pagar por este goce un precio determinado.

$14^{\circ}$. Que en caso de autos el inmueble fue arrendado para ser destinado a jardín infantil, así se estipuló por las partes en la cláusula segunda del contrato, como se dijo.

En consecuencia, si por un hecho imputable al actor, como lo es la falta de recepción municipal del inmueble de Angol 298, la arrendataria no ha podido entrar en el goce de la cosa, necesario es concluir que ha fallado la obligación principal que el contrato le impone al arrendador $y$, por ende, la arrendataria tiene derecho a ponerle término.

No basta que en el contrato se haya autorizado a la arrendataria para solicitar a la I. Municipalidad el cambio de destino de la propiedad arrendada.

Era necesario, además, que el inmueble estuviese en condiciones de que, cumplidas las exigencias para el cambio de destino, se otorgara el permiso municipal.

Se encuentra acreditado en autos que la demandante realizó la gestión destinada a obtener el permiso y ésta fracasó por cuanto el inmueble no contaba con la recepción municipal, de manera que no es imputable a la arrendataria tal fracaso".

En el tercer caso -el del minigolf- también se demanda la terminación del contrato de arrendamiento en conformidad a los artículos 1932 y 1933 del Código Civil. La Corte de Apelaciones de Santiago consideró que había existido el incumplimiento, en los siguientes términos:

"Que en relación a las condiciones en que habría sido entregado el inmueble al demandante, el mérito del expediente permite sostener que éste no se encontraba, efectivamente, en condiciones de ser utilizado por ésta, para los fines que se propuso al arrendarlo y que eran de sobra conocidos por la demandada.

En efecto, no resulta suficiente el acta de entrega del predio, donde consta que no se hicieron reservas de ninguna especie, para concluir que el arrendador cumplió con su obligación, toda vez que, como ha quedado establecido en autos, los problemas presentados por el inmueble estaban en su estatuto o condición jurídica, que le impedía obtener la 
autorización municipal correspondiente para llevar a cabo las actividades de mini golf proyectadas, mientras no se hubiera otorgado la recepción final de las obras que existían en el predio mayor, lo que suponía adoptar la Línea Oficial y considerar la existencia de una franja del predio afecta a utilidad pública, que de no ser expropiada por la autoridad, había de ser cedida a ésta por su dueño".

Por su parte, la Corte Suprema, confirmó la sentencia de la Corte de Apelaciones de Santiago ${ }^{41}$.

En el cuarto caso -arrendamiento de un inmueble para establecer una oficina comercial- La Corte vuelve a acudir al artículo 1932 del Código Civil para poner término al contrato de arrendamiento, señalando lo siguiente:

"8) Que consta de la cláusula primera del contrato de arrendamiento que da origen a estos autos, que el contrato se celebró con el objeto preciso de destinar el inmueble arrendado a oficinas comerciales, a efectos de lo cual el arrendador se comprometió a suscribir todo documento tendiente a la 'normal operación de la propiedad como oficina comercial' que pudieran pedir las autoridades competentes.

$9^{\circ}$ ) Que con el mérito de los antecedentes que obran en autos $y$, en especial, del certificado de fojas 98, emitido por el Director de Obras Municipales de la Municipalidad de Las Condes en respuesta al oficio del tribunal, ha quedado establecido que de acuerdo al Plan Regulador Comunal vigente, en la zona de uso de suelo donde se ubica el inmueble dado en arrendamiento, no se permite la actividad de oficina comercial, lo que significa que éste no sirve o no es apto para el destino para el que fue entregado en arriendo.

10) Que el artículo 1932 del Código Civil otorga al arrendatario el derecho a poner término al arrendamiento, si el mal estado o calidad de la cosa le impide hacer de ella el uso para que ha sido arrendada, sea que el arrendador estuviese o no en conocimiento de tal circunstancia, derecho que puede devenir en una rebaja de la renta si el juez estima que el impedimento para el goce de la cosa es parcial.

Este derecho no es más que una expresión de la obligación de garantía que va envuelta en todos los contratos onerosos, destinada a asegurar que la cosa entregada o transferida sirva para el uso para el cual fue adquirida o recibida, según el caso. En consecuencia, las hipótesis

${ }^{41}$ Corte Suprema, rol No 1287-2008, de 19 de mayo de 2008. 
contempladas en la norma en comento -mal estado de la cosa o la calidad de ésta- deben entenderse en función del objetivo esencial, cual es que impidan que la cosa sirva para el objeto para el cual fue destinada.

Si nos atenemos al sentido natural del término, hemos de entender que la calidad se refiere a la propiedad o conjunto de propiedades, esto es, a las condiciones que hacen apta una cosa para una determinada función, de donde resulta que si, como ocurre con el inmueble de autos, éste no reúne las condiciones necesarias o no tiene la calidad que le permitiría ser destinado a oficina comercial -que es el uso para el cual el arrendatario celebró el contrato- se da el supuesto de hecho que habilita al arrendatario para pedir la terminación del contrato.

$\left.11^{\circ}\right)$ Que así las cosas este tribunal acogerá la acción reconvencional del demandado en orden a declarar terminado el contrato de arrendamiento por los fundamentos antes expresados".

Tratándose del quinto caso -el de las deudas de agua potable y luz eléctrica- la Corte de Apelaciones de Santiago declara terminado el contrato de arrendamiento estimando, según lo dispuesto en el artículo 1932, que la arrendadora había cumplido con sus obligaciones. El razonamiento es el siguiente:

"Segundo: Que conforme con el artículo 1924 del Código Civil, es obligación del arrendador, en lo pertinente, mantener la cosa en estado de servir para el fin a que ha sido arrendada y librar al arrendatario de toda perturbación o embarazo en el goce de la cosa arrendada.

Desde luego, la existencia de deudas de alto monto, anteriores a la suscripción y vigencia del contrato, con el suministro de agua suspendido y es de presumir igual hecho respecto de la luz eléctrica, atendido el alto monto los consumos impagos, no permiten que el inmueble pueda ser destinado a casa habitación, que fue la finalidad para la que fue arrendada por la demandante, al tenor de la cláusula segunda del contrato que rola a fs. 1, no objetado de contrario.

De otra manera, la arrendadora no acreditó haber asistido o socorrido a la actora en aquella perturbación o embarazo para el uso de la cosa, no obstante la obligación legal sobre el punto que pesaba en su contra.

Tercero: Que las cláusulas tercera y cuarta del contrato de arrendamiento que rola a fs. 1, no logra establecer la obligación de la arrendataria de pagar los servicios básicos anteriores a la ocupación del inmueble por 
su parte, sea porque sólo declara recibir el bien raíz en buen estado de conservación y la obligación del pago de esos consumos en forma mensual, esto es, referido al tiempo de vigencia del vínculo contractual, más no al tiempo anterior.

El compromiso de pagar las deudas de luz eléctrica y de agua potable no se divisa en el contrato, ni tampoco es de presumir esa obligación, debido al bajo monto de la renta y que representa los dos tercios del total de las deudas por esos servicios básicos, consumos impagos de los que no se hizo mención en el contrato.

Cuarto: Ante el incumplimiento por parte de la arrendadora de obligaciones esenciales del contrato que unía a las partes, procede dar por terminado el contrato de arrendamiento conforme lo dispone el artículo 1932 del Código Civil, así como ordenar la restitución de las rentas pagadas y que alcanzan a un millón noventa mil pesos (\$1.090.000.-), según da cuenta la cláusula sexta del contrato de autos, al tenor de lo señalado en el artículo 1933 del mismo cuerpo legal antes citado".

En el sexto caso -el inmueble que fue arrendado para un uso que no permitían las reglas del condominio en el que se encontraba- la Corte Suprema confirma la sentencia de la Corte de Apelaciones que declaró terminado el contrato de arrendamiento por incumplimiento de los artículos 1924 y 1932, señalando lo siguiente:

"(...) los jueces del grado estimaron que el demandado principal incurrió en incumplimiento contractual conforme disponen los artículos 1924 No 2 y 1932 del Código Civil, puesto que, en los hechos, la calidad de la cosa, en tanto bien cuya destinación es exclusiva para usos relacionados con prestaciones médicas o de otra actividad autorizada expresamente por los copropietarios, impide a la demandante utilizar el bien arrendado para los fines que contrató, configurándose una causa legal de terminación del contrato de arrendamiento".

Finalmente, en el séptimo caso, la Corte Suprema consideró lo siguiente:

"Que en lo que dice relación con las alegaciones referidas precedentemente, cabe señalar que no se advierten infracciones de la ley acusadas, toda vez que, de conformidad a lo dispuesto en los artículos 1915 y 1932 del Código Civil, nace para el arrendador la obligación de otorgar al arrendatario el goce del inmueble de acuerdo al uso acordado en la respectiva convención, siendo procedente su terminación e indemnización de perjuicios si la calidad de las cosa impide hacer uso para lo que fue arrendada". 
¿Qué puede concluirse de este conjunto de sentencias? Acaso lo primero y más evidente sea que, según lo han entendido los tribunales superiores de justicia, al menos en los últimos años ${ }^{42}$, la tutela del arrendatario no solo alcanza a cuestiones que podríamos denominar de disconformidad material, es decir, aquellas en que la materialidad de la cosa no termina de adecuarse a lo que exige el contrato, sino que, además cubren aspectos de disconformidad jurídica. Y dentro de estos aspectos, encontramos no solo la presencia de derechos de terceros según lo dispone el artículo 1931, sino que, también, lo que hemos denominado "vicios jurídicos".

En segundo lugar, la peculiaridad de estos vicios jurídicos es que se trata de cuestiones que no afectan a la materialidad de la cosa, sino a su situación legal en términos que, como ya ha quedado dicho, impiden u obstaculizan aquello que garantiza el contrato al arrendatario.

En tercer lugar, una mirada a las sentencias muestra que, generalmente, estos vicios se configuran al abrigo de regulación administrativa referente a permisos o a limitaciones en el uso del suelo. Sin embargo, no se agota allí. Así lo demuestra el hecho de que en un caso el problema sea la existencia de cuantiosas deudas por servicios básicos y en otro, las limitaciones en el uso de los inmuebles que establecía el reglamento de copropiedad que disciplinaba el uso del inmueble en cuestión.

En cuarto lugar -y generalizando la conclusión anterior- el lenguaje de los tribunales parece indicar que lo relevante no es si se trata de una cuestión atingente a la materialidad de la cosa arrendada o a su situación jurídica, ni de qué forma exactamente afecte a su situación jurídica. Lo que parece realmente relevante es que obstaculice o impida el uso que el contrato de arrendamiento garantizaba al arrendatario.

Esta última conclusión que según se verá -y salvo una conspicua excepción- no ha llamado particularmente la atención de la doctrina nacional, es cualquier cosa menos novedosa para los tribunales superiores de justicia chilenos. A este respecto, convendrá recordar la sentencia de la Corte Suprema de 1941, citada por la sentencia de la Corte de Apelaciones de Santiago de 27 de enero de 1998 según la cual:

“(...) lo fundamental para el ejercicio de la acción que concede el artículo 1932 del Código Civil es el lecho de ser imposible el uso de la cosa arrendada, cualquiera que sea el motivo o circunstancia que lo produzca".

\footnotetext{
${ }^{42}$ Sin embargo, convendrá recordar la sentencia de la Corte Suprema de 1941 que cita uno de los fallos, Corte Suprema, rol № 7205-2015, de 13 de agosto de 2015.
} 
La conclusión, aunque extremadamente correcta desde una concepción amplia y unitaria del incumplimiento contractual ${ }^{43}$, no deja de ser sorprendente al abrigo de las reglas del Título XXVI del Libro IV del Código Civil.

La razón es la siguiente, los artículos 1932 a 1934 parecen disciplinar la garantía de los vicios redhibitorios en el contrato de arrendamiento ${ }^{44}$. De una parte, los tres artículos (1932, 1933 y 1934) emplean la expresión "vicio"; de otra parte, Pothier, en su Tratado al cual, según hemos dicho, se acudió para la redacción del Título XXVI del Libro IV, señala que la acción del arrendatario en estos casos: "pertenece en cierta manera á las redhibitorias, y es análoga á la de esta especie que tiene un comprador contra su vendedor por razon de los vicios redhibitorios de la cosa vendida..." ${ }^{45}$.

Pues bien, si de lo que se trata es de disciplinar la presencia de vicios redhibitorios como sucede en la compraventa, habría que estar de acuerdo con Alessandri Rodríguez respecto de la siguiente conclusión: "Los vicios redhibitorios suponen defectos intrínsecos en la cosa, emanados de sí misma y no de actos externos" ${ }^{46}$. Una mirada a los ejemplos de Pothier sobre esto ${ }^{47}$ y a los que considera Zimmermann en el derecho romano y medieval a este respecto, muestran que Alessandri parece estar en lo cierto ${ }^{48}$. El punto, sin embargo, es que en todos los casos que se han mencionado los defectos no son intrínsecos, sino que emanados de actos externos como, dicho sea de paso, suele acontecer con los defectos jurídicos ${ }^{49}$.

El hecho de que se hayan empleado los artículos 1932 y siguientes para enfrentar cuestiones relacionadas con vicios jurídicos no parece, según se ha dicho, haber Ilamado demasiado la atención de la doctrina nacional ${ }^{50}$. La excepción, hasta donde llegan nuestras noticias es Orrego Acuña ${ }^{51}$. Según este autor, el artículo 1932 contemplaría dos hipótesis, la primera es el mal

\footnotetext{
43 Morales (2006); Vidal (2007), pp. 495 y ss.; Vidal (2009a), pp. 41-59; Pizarro (2008), pp. 395-402; De la MaZa (2011), pp. 629-663.

${ }^{44}$ En el ámbito nacional así los considera, por ejemplo, Orrego (2011), p. 181. En el derecho español puede consultarse CÁmARA (2008), pp. 350-356.

45 Pothier, (1841), p. 64, No 116.

46 Alessandri (2003), p. 213.

47 POTHIER (1841), pp. 63 y ss.

48 ZimMermanN (1992), pp. 365-369.

49 Una mirada a Pothier (1841), pp. 61-63, № 110-114, muestra que todos los ejemplos de que se sirve para ilustrar vicios en el arrendamiento corresponden a vicios materiales, así, por ejemplo, las yerbas venenosas en un prado, la porosidad de la madera de una cuba, la ceguera de un caballo.

50 Ver ZimmermanN (1992), pp. 362-369.

51 Orrego (2011), pp. 182-183.
} 
estado de la cosa y la segunda la calidad de la cosa. El mal estado se referiría a la situación material de la cosa, en tanto, la calidad sería un concepto más elástico que permitiría cubrir cualquier supuesto -material o jurídico-, pues lo determinante sería su efecto: impedir u obstaculizar el uso de la cosa garantizado por el contrato. Como ya se ha visto, los tribunales parecen asignar a la expresión "calidad" la misma elasticidad que le atribuye Orrego. Un buen ejemplo es la sentencia de la Corte de Apelaciones de Santiago de 6 de enero de 2000 ya citada ${ }^{52}$, en la que se señala que: "la calidad se refiere a la propiedad o conjunto de propiedades, esto es, a las condiciones que hacen apta una cosa para una determinada función".

En definitiva, entonces, todo indica que frente a la presencia de un vicio jurídico, en el sentido que hemos venido empleando esa expresión aquí, la tutela de arrendatario queda determinado por el régimen de los artículos 1932 a 1937, es decir, por parte de las normas que disciplinan la obligación del arrendador de mantener la cosa en estado de servir para el fin a que ha sido arrendada.

Al igual que como sucede con la evicción, las reglas de saneamiento de los vicios en el arrendamiento ofrecen tanto garantías como responsabilidad; aunque, a diferencia del arrendamiento, la indemnización, al menos del daño emergente, no exige un juicio de reproche al arrendador ni la existencia de un pacto de saneamiento ${ }^{53}$.

\section{La expiración del contrato de arrendamiento}

Como ya ha quedado dicho, la tutela del arrendatario frente a la existencia de turbaciones jurídicas no se agota en el régimen de los saneamientos. Resulta, además, necesario considerar algunas causales de expiración del contrato en las cuales lo que determina su término es, precisamente, la presencia de una turbación jurídica, a la que denominamos "derecho sobreviniente" y que -se verá a continuación-funciona de manera semejante al incumplimiento contractual en el sentido de que reconoce al arrendatario una tutela frente a la imposibilidad de seguir empleando la cosa para el fin a que ha sido arrendada.

\footnotetext{
52 Corte de Apelaciones de Santiago, rol № 7153-2008, de 6 de enero de 2010

${ }^{53}$ En este sentido, el inciso primero del artículo 1933 impone al arrendador la obligación de indemnizar el daño emergente provocado por los vicios cuya causa sea anterior al contrato, aun cuando hayan sido desconocidos por el arrendador. Sobre la compleja situación de la indemnización del daño provocado por esos vicios en el derecho romano puede consultarse ZimmERMANN (1992), pp. 365-366.
} 


\section{Los artículos 1958 y 1961 como supuestos de derechos sobrevinientes}

A diferencia del contrato de compraventa, en el de arrendamiento los derechos de terceros sobre la cosa pueden surgir con posterioridad al perfeccionamiento del contrato. El Código Civil trata esta materia de manera levemente oblicua, considerando el otro extremo de la relación: el arrendador y la pérdida de su derecho sobre la cosa.

La cuestión es explícitamente tratada en el artículo 1961, pero, en nuestra opinión, debe considerarse también el artículo 1958. La razón es sencilla. Para advertirla basta considerar el inciso segundo de este último artículo:

"Si, por ejemplo, el arrendador era usufructuario o propietario fiduciario de la cosa, expira el arrendamiento por la llegada del día en que debe cesar el usufructo o pasar la propiedad al fideicomisario; sin embargo de lo que se haya estipulado entre el arrendador y el arrendatario sobre la duración del arriendo, y sin perjuicio de lo dispuesto en el artículo 794, inciso $2^{\circ \prime \prime}$.

Como se ve, extingue el derecho del arrendador qua usufructuario o propietario fiduciario, por lo mismo, sobreviene el derecho de un tercero que antes tenía la calidad de fideicomisario o nudo propietario sobre la cosa.

Ya se ha dicho que, a diferencia de como lo consideraba Pothier ${ }^{54}$, el Código Civil trata la situación de los derechos sobrevinientes a propósito de la expiración del contrato de arrendamiento y no de la garantía por evicción.

Particularmente respecto del artículo 1961, esta forma de resolver el problema se conecta con el derecho romano y Las Partidas en el sentido en que, entre la protección del arrendatario y la del titular de los derechos sobrevenidos, se opta por tutelar al segundo en desmedro del primero ${ }^{55}$ con las excepciones propias del artículo $1962^{56}$. Habrá que advertir, sin embargo, que, a diferencia

\footnotetext{
${ }^{54}$ Ver POTHIER (1841), pp. 47 y ss.

55 Sobre esta solución y su conexión con el derecho romano y Las Partidas ver Cámara (2008), pp. 365-370.

56 Sobre el sentido del enunciado "estarán obligados a respetar el arrendamiento", ver comentario de sentencia DE LA MAZA (2013). El artículo 1962 regula tres casos en los que determinados sujetos que se indica en la norma, están obligados a respetar el arrendamiento, a saber, los adquirentes a título lucrativo $\left(\mathrm{N}^{\circ} 1\right)$, adquirentes a título oneroso $\left(\mathrm{N}^{\circ} 2\right)$ y los acreedores hipotecarios $\left(\mathrm{N}^{\circ} 3\right)$, todos, según los respectivos supuestos que se detallará a continuación.

En el del $N^{0} 1$, debe respetar el arriendo "aquel a quien se transfiere el derecho del arrendador por un título lucrativo", como herederos, legatarios y donatarios del arrendador, en este sentido VODANOVIC (1942), p. 468; MeZA (2007), p. 113, y CORNEjO (2012), p. 135, salvo este último respecto a la inclusión de los herederos, ya que estima que ellos están obligados a respetar el arrendamiento no con cargo al artículo 1962, sino al artículo 1097, en tanto pasan a ser partes del contrato. Otro punto a destacar en este numeral, es que Meza explica que la voz "lucrativo" no debe llamar a equívocos, y se debe
} 
del derecho romano, donde la cuestión era de inoponibilidad del contrato de arrendamiento frente al tercero e incumplimiento contractual frente al arrendador $^{57}$, en el Código Civil es tratada en sede de expiración del contrato.

En términos de derecho comparado la cuestión no es, en absoluto, pacífica, existiendo una disparidad de soluciones ${ }^{58}$. Sin embargo, no es esto lo que nos interesa discutir aquí. La razón de que omitamos esta discusión es que la doctrina y los tribunales nacionales parecen estar de acuerdo en que se trata de un caso de extinción del contrato y no de incumplimiento.

Que la presencia de derechos sobrevinientes de terceros se encuentre disciplinada en sede de extinción del contrato no debe, sin embargo, obscurecer el hecho de que existe aquí una turbación jurídica respecto del arrendatario y es, precisamente, esta turbación la que explica que el arrendador deba indemnizar al arrendatario.

\section{2. ¿Cuándo se produce la turbación jurídica?}

Puestas las cosas de esta manera, la pregunta ha de ser cuándo se produce la turbación jurídica para el arrendatario. Y, como se verá de inmediato, las posibilidades son dos.

entender como "gratuito" en el mismo sentido, Vodanovic (1942), p. 468. Señala Meza (2007), p. 113, que lucrativo se "mira desde el punto de vista del cesionario, y el título es lucrativo para el arrendador cesionario, cuando no ha pagado ningún precio por la cesión".

Sobre el $\mathrm{N}^{\circ}$ 2, se debe señalar que rige para todo "aquel a quien se transfiere el derecho del arrendador, a título oneroso, si el arrendamiento ha sido contraído por escritura pública; exceptuados los acreedores hipotecarios". El contrato, según MEZA (2007), p. 113, consta de un modo fehaciente y fecha cierta, de modo que los adquirentes quedan en situación de conocerlo, y, si efectúan la adquisición de la cosa arrendada, lo hacen a sabiendas de la existencia del arrendamiento. No obstante, sobre este punto ORREGo (2011), p. 342, Ilama la atención acerca de que la disposición sólo exige que el arrendamiento conste por escritura pública, pudiendo o no estar inscrita, norma que -continúa Orregose explicaría por la época que entró en vigencia el Código Civil, pero que en nuestros días resultaría muy peligrosa ya que no asegura una adecuada manera de enterarse si pesa o no un arrendamiento sobre el bien que se adquiere, en el mismo sentido Cornejo (2012), p. 137.

Por último, el numeral 3, regula el caso de los acreedores hipotecarios, conforme al cual estos deberán respetar el arrendamiento si este "ha sido otorgado por escritura pública inscrita en el Registro del Conservador antes de la inscripción hipotecaria". Como señala Meza (2007), p. 114, el numeral está pensado para los acreedores hipotecarios que se adjudiquen la finca hipotecada para hacerse del pago de sus créditos, los cuales deberán respetar el arrendamiento siempre que se cumpla con que el contrato i) conste por escritura pública, ii) se haya inscrito en el Registro del Conservador, y iii) que dicha inscripción se haya efectuado antes de la inscripción hipotecaria. Sobre la discusión que surge en este numeral, acerca de si se debe seguir la regla del $1962 \mathrm{~N}^{\circ} 2$ o № 3 en el caso que quien se adjudica la finca hipotecada no es el acreedor hipotecario, sino un tercero adquirente, ver por todos CORneJO (2012), pp. 140-144.

57 Sobre esto ver las citas de Cámara (2008), pp. 365-366, nota 350.

${ }^{58}$ Sobre el tema Cámara (2008), pp. 370-377. 


\section{a. La turbación se produce al momento en que el arrendador pierde su derecho}

Una posible respuesta es en el momento de la privación total o parcial de la cosa arrendada como sucedía con la evicción. Sin embargo, no es la única respuesta, otra posible $-y$, desde luego, más cercana a la letra del artículo 1961- es que la turbación se produce con término del contrato de arrendamiento, aun cuando no se haya privado al arrendatario de la cosa arrendada. Y esta segunda cuestión nos lleva a preguntarnos cuándo se termina el contrato.

Tanto en la doctrina nacional como en la opinión de los tribunales resulta predominante la idea de que el contrato termina en el momento en que el arrendador pierde su derecho.

Así, por lo que toca a la doctrina, Ducci Claro sostiene que "la extinción del derecho del arrendador pone fin al contrato, aunque esta extinción le sea imputable" 59 . Por su parte, Quintanilla Pérez señala:

"En el Código Civil al extinguirse el derecho del arrendador sobre la cosa arrendada -excepto los casos en que pueda ser oponible al adquirente y sin perjuicio de la responsabilidad del arrendador frente al arrendatario- el contrato de arrendamiento se extingue ipso jure ${ }^{60 \prime \prime}$.

Escribiendo sobre el tema, Cornejo señala que:

"La terminación del contrato por la extinción del derecho del arrendador opera ipso iure" ${ }^{\prime \prime 61}$.

Se trata de una idea que también parece haber ganado tracción en la opinión de los tribunales superiores de justicia. En algunos casos, los tribunales han justificado esta consecuencia estimando que resuelto el derecho de quien concede, resuelto queda el derecho concedido (resoluto jure dantis resolvitur jus accipientis). Así, por ejemplo, en un caso de usufructo sobre un inmueble dado en arrendamiento, la arrendadora demandó término del contrato por no pago de una renta; en tanto, la arrendataria se defendió señalando que, por haber muerto el usufructuario, queda sin efecto dicho contrato por la extinción del derecho del arrendador, y por tanto no le adeudaba dicha renta.

Al respecto, en primera instancia se acoge la demanda, y es confirmada por sentencia de la Corte de Apelaciones, ante la cual se interpone un recurso de casación en el fondo en el que la Corte Suprema acoge el recurso estimando, sobre el asunto en comento, lo siguiente:

\footnotetext{
59 DuCCI (1982).

60 Quintanilla (1977), pp. 177-178.

${ }^{61}$ Cornejo (2012), p. 226.
} 
"Cuarto: Que debe tenerse presente, además, que la extinción del derecho del arrendador pone fin al contrato por aplicación del principio fundamental que enuncia el aforismo Resoluto jure dantis resolvitur jus accipientis.

El arrendador se obliga a procurar al arrendatario el goce de la cosa y ésta obligación, de carácter sucesivo, se prolonga durante la vigencia del contrato.

Sin embargo, la pérdida de los derechos que el arrendador tenía en la cosa lo coloca en la imposibilidad de satisfacer sus obligaciones y, por ende, determina la extinción del contrato.

A la luz de lo prevenido en el citado inciso segundo del artículo 1958 del Código Civil, cabe reparar que la extinción del derecho del arrendador supone que otra persona adquiere este derecho y que, por otra parte, la expiración de contrato de arrendamiento conllevará a que los terceros que adquieran los derechos que el arrendador perdió, no se encuentren obligados a respetar dicha convención" 62 .

Un segundo argumento del cual se han servido los tribunales para justificar la terminación ipso iure del contrato se relaciona con lo dispuesto por el artículo $7^{\circ}$ de la Ley $N^{\circ} 18.101$, respecto a los juicios que allí se disciplinan. En lo que aquí interesa, el precepto dispone que las reglas del Título III de la ley se aplicarán a los juicios término de contrato (art. $7^{\circ} \mathrm{N}^{\mathrm{o}} 1$ ), y de restitución por extinción del derecho del arrendador (art. $7^{\circ} \mathrm{N}^{\circ} 4$ ).

Así, por ejemplo, en un caso en que unos herederos vendieron la propiedad arrendada por el causante, la Corte Suprema estimó que la terminación del contrato de arrendamiento se produce de pleno derecho, al momento de celebrarse el contrato de compraventa en noviembre de 2012:

"Quinto: La extinción del derecho del arrendador se produce de pleno derecho y una demostración de que ello es así, se encuentra en la Ley $N^{\circ} 18.101$, en su artículo $7^{\circ}$, al establecer entre los juicios que se ventilan conforme a esas normas, el de 'restitución por extinción del derecho del arrendador'. Vale decir, lo que se solicita al juez es que ordene la restitución de la cosa arrendada, basado en que operó la extinción del derecho del arrendador, lo que supone que no es previa su declaración, sino solo su constatación. Por lo cual, en lo que respecta a la obligación

${ }^{62}$ Corte Suprema, rol No 5094-2007, de 2 de julio de 2008. 
de restituir los bienes, el sentenciador ha aplicado correctamente el derecho" ${ }^{\prime \prime 3}$.

La misma idea se encuentra con cierta frecuencia en otras sentencias sobre casos semejantes ${ }^{64}$. La expresa, claramente, una sentencia de la Corte de Apelaciones de Concepción en la que se lee lo siguiente:

"3.- Que el artículo 1950 No 3 del Código Civil, dispone que el contrato de arrendamiento expira por la extinción del derecho de arrendador y ello ocurre, precisamente, entre otras situaciones, cuando el arrendador vende la cosa arrendada, tal cual se prescribe en el artículo 1961 del Código Civil.

En ese evento, es la sola pérdida del derecho que facultaba dar la cosa en arrendamiento la que produce la terminación del contrato y, como es principio contractual el que estos negocios jurídicos terminan por un solo modo, resulta de toda evidencia que, habiendo expirado ya el contrato por la venta del bien arrendado, no puede pretenderse que sea necesario, además, ejercer una acción para demandar esa misma terminación.

Es por ello que el artículo $7^{\circ}$ de la Ley No 18.101 que regula el arrendamiento de predios urbanos, distingue entre la acción de terminación del arrendamiento $\left(\mathrm{N}^{\circ} 2\right)$ y la de restitución de la propiedad por extinción del derecho del arrendador $\left(\mathrm{N}^{\circ} 4\right)^{\prime \prime 65}$.

Pues bien, si se acepta que el contrato se extingue con la pérdida del derecho del arrendador, aún resulta necesario examinar cuándo ha de entenderse perdido dicho derecho. La respuesta, a primera vista, no parece enigmática: tratándose de la transferencia de inmuebles -el caso más frecuente-, en el momento de la inscripción a nombre del nuevo adquirente. Así, por ejemplo, en una sentencia de la Corte Suprema de 27 de octubre de 2015 se lee:

"Que habiéndose acreditado la venta del predio rústico por el arrendador a la sazón dueño del inmueble, cesó su derecho sobre la cosa, conforme lo dispuesto en el artículo 1961 del Código Civil, dejando de ser parte en el contrato de arrendamiento, por el solo ministerio de ley una vez inscrita la propiedad a nombre de los compradores. Éstos,

\footnotetext{
${ }^{63}$ Corte Suprema, rol No 28606-2014, de 5 noviembre de 2015.

${ }^{64}$ Corte Suprema, rol No 21540-2014, de 9 de junio de 2015; Corte Suprema, rol № 5559-2014, de 24 de diciembre de 2014; Corte de Apelaciones de Temuco, no registra rol, de 13 de abril de 1987.

${ }^{65}$ Corte de Apelaciones de Concepción, rol № 3780-2001, de 14 de julio de 2006.
} 
conforme la parte final del mismo artículo 1961 del Código Civil, son sucesores a título singular en el respectivo contrato de arrendamiento, al que quedan obligados, salvo acuerdo con el arrendatario, según lo dispuesto en el artículo 10 del D.L. Nº 993, aplicable en la especie.

Tercero: Que habiendo cesado su calidad de arrendador, el demandante carece de legitimación activa para demandar el término del contrato de arrendamiento por no pago de rentas, asistiéndole sólo el derecho a reclamar el pago de aquellas insolutas en el período anterior a la inscripción de la compraventa a nombre de los terceros adquirentes, que comprende los meses de abril a junio de 2013, más 18 días del mes de julio del mismo año"66.

La misma idea ha sido reiterada en numerosas ocasiones por los tribunales superiores de justicia ${ }^{67}$.

Tratándose del arrendamiento de inmuebles, entonces, el contrato se extinguiría ipso iure al momento de la pérdida del derecho del arrendador. Esta podría estimarse como la opinión mayoritaria de los autores y los tribunales.

\section{b. La turbación se produce por la imposibilidad del arrendador de entregar el uso y el goce de la cosa al arrendatario}

Sin embargo, encontramos que una reciente sentencia de la Corte Suprema de 31 de mayo de 2016 refuerza la idea, estableciendo de que no basta la pérdida del derecho del arrendador, sino que es necesario que dicha pérdida determine una imposibilidad manifiesta de entregar el uso y goce de la cosa al arrendatario ${ }^{68}$. En el caso en comento dos sociedades celebraron en el año 2008 un contrato de arrendamiento por diez años sobre un inmueble que incluía amoblado y equipamiento para que el inmueble fuera destinado a discoteca, entregando el uso de una patente comercial y de alcoholes. Posteriormente, en el año 2009 el inmueble objeto del contrato fue aportado por la arrendadora a la creación de una nueva sociedad, en la cual tenía participación.

\footnotetext{
${ }^{66}$ Corte Suprema, rol No 32147-2014, de 27 de octubre de 2015.

${ }^{67}$ Corte de Apelaciones de Valparaíso, rol No 712-2009, de 30 de septiembre de 2009; no señalando que se produce específicamente al momento de la inscripción, pero sí que se produce al momento de venderse el inmueble: Corte de Apelaciones de Santiago, rol № 8191-2012, de 11 de octubre de 2013; Corte de Apelaciones de Santiago, rol № 2366-1993, de 17 de agosto de 1993; Corte Suprema, rol No 31948-2014, de 26 de marzo de 2015.

${ }^{68}$ Corte Suprema, rol № 6436-2016, de 31 de mayo de 2016.
} 
En julio del 2010, la Municipalidad ordenó la clausura inmediata del recinto por causas no imputables a la demandada, momento en el cual la arrendataria dejó de pagar las rentas de arrendamiento.

Sobre la base de dichos presupuestos fácticos, se concluyó rechazar la demanda principal, toda vez que la causal de término de contrato invocada, esto es, la del numeral tercero del artículo 1950 del Código Civil, solo opera cuando se impide al arrendador en forma absoluta cumplir con la obligación de ceder el goce de la cosa, excluyendo de su aplicación aquellos casos en que perdiendo su derecho sobre ésta, el arrendador puede seguir cumpliendo con la obligación, como ocurrió en la especie.

El arrendatario recurre contra la sentencia de la Corte de Apelaciones, que confirmaba la de primera instancia, alegando que:

"Segundo: Que el recurrente reclama que el fallo impugnado infringió el artículo 1950 en relación con los artículos 1961 y 19, todos del Código Civil. En síntesis, sustenta la infracción en que debió acogerse la demanda principal pues se acreditó que el arrendador perdió el derecho de usar y gozar el inmueble objeto del contrato, produciéndose su terminación ipso iure.

Refiere que los sentenciadores yerran al agregar, de manera arbitraria, un requisito adicional para la terminación del contrato por extinción del derecho del arrendador, como lo es que la pérdida del derecho implique una imposibilidad manifiesta de entregar el uso y goce de la cosa al arrendatario, lo que no se encuentra incorporado en el artículo 1961 del Código Civil".

A lo anterior, la Corte Suprema señaló que:

"Cuarto: Que no se advierten las infracciones acusadas por el recurrente, sino que se aprecia que los sentenciadores del fondo aplicaron correctamente la ley, teniendo en consideración que la transferencia del dominio realizada por la demandada dueña de la propiedad a una sociedad en la que tenía participación, no extinguió el contrato de arrendamiento, manteniendo la actora el uso y goce de la cosa, máxime si ésta siguió pagando las rentas y usando la propiedad hasta la clausura del local por causas no imputables a la demandada".

Existen ciertas cuestiones fácticas -el hecho de que la demandada haya tenido participación en la sociedad que compró el inmueble y que se haya seguido usando la propiedad y pagando la renta- que inducen a simpatizar con la sentencia de la Corte Suprema. Por otra parte, algún autor había sugerido 
ya una lectura de la extinción del derecho del arrendador en esa clave ${ }^{69}$. En tercer lugar, se trata de una solución que tiene antecedentes históricos en D. 19.2.25.1, allí Gayo señala lo siguiente:

"El arrendatario de un fundo o de una habitación, si por algún motivo vende el fundo o la casa, debe precaverse de que sea permitido al colono disfrutar y al inquilino habitar en las mismas condiciones, por parte del comprador; si no, el arrendatario impedido podrá demandarle por la acción de conducción".

Como puede verse, el derecho romano disponía una solución semejante, aunque -como ya ha quedado dicho- a través de un camino distinto: el del incumplimiento contractual.

Y esta cuestión ha de llevarnos a pensar si la sede correcta para considerar la situación de los derechos sobrevinientes es la de la expiración del contrato o, en cambio, ha de ser la del incumplimiento contractual.

En nuestra opinión, el acomodo de esta cuestión en la disciplina del incumplimiento permitiría explicar en términos dogmáticamente más satisfactorios la indemnización que debe el arrendador pues todo parece indicar que debe indemnizar precisamente porque ha incumplido con su obligación de liberar al arrendatario de turbaciones jurídicas ${ }^{70}$.

${ }^{69}$ Ver CoRnejo (2012), pp. 225-226.

70 Se ha sostenido que el régimen de tutela del arrendatario debiese ser la de la expiración del contrato, pues al desprenderse de su derecho, el arrendador queda en la imposibilidad de cumplir con sus obligaciones CORNEJO (2012), p. 226.

El argumento no nos parece dogmáticamente persuasivo. De una parte, a diferencia de la destrucción total de la cosa arrendada, y como lo muestra la última de las sentencias de la Corte Suprema, no es verdad que el arrendador no pueda seguir cumpliendo con sus obligaciones. Por otra parte, si fuera el caso que quien no tiene derechos está imposibilitado de cumplir sus obligaciones ¿cómo podría explicarse la validez del arrendamiento de cosa ajena?

Probablemente, el problema que intenta resolver esta regla es la situación del tercero adquirente a quien no es oponible el contrato, pero si ese fuera el caso, no es necesario entender que el contrato se terminó. En virtud de los efectos relativos del contrato, aun sin las normas de la expiración, en principio, no sería oponible al tercero que adquiere la cosa arrendada, salvo en los supuestos del artículo 1962. Decimos "en principio", porque en este tema nos topamos con la figura del precario, y todo aquello que parece obvio se torna confuso cuando se examina la frondosa y caótica opinión de los tribunales al respecto. De esta manera, los tribunales superiores de justicia parecen no encontrar ningún obstáculo en asumir que un contrato de arrendamiento que, en virtud del artículo 1961, debería considerarse como extinto, sirva como título para oponerse a la acción del precarista. En este sentido, puede consultarse la sentencia de Corte Suprema, rol No 3475-2015, de 27 de octubre de 2015, en que al actual dueño, y demandante de la acción de precario, se le opone un contrato de arriendo entre la demandada con la antigua dueña del inmueble, y, en virtud de este, la acción de precario es rechazada, o en Corte de Apelaciones de Santiago, rol No 9156-2015, de 16 de octubre de 2015, donde la demandada ha invocado, para justificar la tenencia del inmueble, un contrato de arrendamiento sobre una casa habitación y terreno, en el que comparece como arrendador un tercero y el actual 
Como sea que fuere, en el ámbito nacional, en general, el diagnóstico frente a los derechos de terceros es que el contrato de extingue una vez que el arrendador ha perdido su derecho. Por otra parte, generalmente, se asume que, tratándose de inmuebles el caso más frecuente esa pérdida se produce con la enajenación de la cosa (aunque es necesario tener en cuenta la última sentencia de la Corte Suprema citada y prestar atención a si hará o no fortuna hacia el futuro y en qué términos) y frente a esta turbación jurídica, la tutela del arrendatario corresponde a una indemnización de perjuicios.

\section{A manera de conclusión: simplificar las cosas}

Una mirada al régimen de tutela del arrendatario frente a la presencia de perturbaciones jurídicas que impidan u obstaculizan el uso de la cosa que garantiza el contrato, muestra que dicha tutela queda disciplinada ya sea por el régimen del saneamiento o por el de la expiración del contrato de arrendamiento.

Nuestras conclusiones son las siguientes.

En primer lugar, respecto de los saneamientos, y comenzando por la evicción. Como se ha visto, su campo de aplicación resulta extraordinariamente restringido, de hecho, no fuimos capaces de encontrar sentencias que se ocuparan directamente de la cuestión. Parece, entonces, que es mejor prescindir de este sistema de garantías y optar, en cambio, por una noción de incumplimiento más amplia que no solo abarque derechos de terceros que ya han sido judicializados, sino que involucre aquellos que aún no lo son.

Respecto de los vicios. La conclusión más sorprendente, es que los jueces han sobrepujado los límites de la disciplina de los vicios redhibitorios para alcanzar a defectos jurídicos que impiden que el arrendatario haga uso de la cosa según el contrato. Paradójicamente, esta forma de entender los vicios redhibitorios provee de una buena pista respecto de por qué deben ser eliminados y, en cambio, absorbidos en una noción amplia de incumplimiento que es como los tribunales los han venido aplicando a propósito de este contrato.

Por lo que toca a la situación de los derechos sobrevinientes de terceros. Las reglas pertinentes indican que si el arrendador pierde su derecho el contrato de arrendamiento expira. La duda que se ha presentado a propósito de

demandado como arrendatario. En la prueba documental rendida, aparece que posteriormente, el arrendador vendió el inmueble a otra persona, y, esta, a su vez, lo vendió a la demandante de autos. La Corte estableció que esta situación "constituye una limitante a la pretensión de la actora, ya que no puede sostener que la tenencia sea por su exclusiva mera tolerancia, resultando que el título esgrimido le resulta oponible". 
una reciente sentencia de la Corte Suprema, es si es suficiente que expire el derecho o ha de ser el caso que, a causa de esa expiración, el arrendador no pueda seguir cumpliendo con sus obligaciones. Nos parece que lo que esa sentencia muestra es que el correcto acomodo de la situación de los derechos sobrevinientes se encuentra en la disciplina del incumplimiento contractual que, por lo demás, explica mejor el hecho de que el arrendador deba indemnizar. Debe indemnizar, precisamente, porque ha incumplido con su obligación de liberar de turbaciones jurídicas al arrendatario.

Como se ve, entonces, nuestra conclusión general es que resultaría deseable simplificar las cosas en lo que se refiere a la tutela del arrendatario frente a la presencia de turbaciones jurídicas, y la forma en que creemos que esto podría hacerse consiste en disponer de una noción amplia y unitaria de incumplimiento contractual que absorbiera tanto el régimen de los saneamientos como parte de la disciplina de la expiración del contrato.

\section{Bibliografía CITADA}

Aburto Barahona, Juan Pablo y De la Maza Gazmurı, Íñigo (2015): "Falta de conformidad jurídica y tutela del comprador" en: lus et Praxis (Vol. 21, $N^{\circ}$ 2), pp. 61-108.

AlesSANDRI Rodríguez, Arturo (2003): De la compraventa y de la promesa de venta (Santiago, Editorial Jurídica de Chile), Tomo II, Volumen I.

Barcia Lemmann, Rodrigo (2007): Lecciones de Derecho Civil chileno (Santiago, Editorial Jurídica de Chile).

Cámara Lapuente, Sergio (2008): El arrendamiento de bienes muebles (Cizur Menor, Aranzadi).

Carrasco Perera, Ángel (2010): Derecho de contratos (Cizur Menor, Navarra, Thomson Reuters).

Cornejo Aguilera, Pablo (2012): El contrato de arrendamiento de bienes raíces urbanos (Santiago, Legal Publishing).

De Castro y Bravo, Federico (1997): El negocio jurídico (Madrid, Civitas).

De la Maza Gazmurı, Íñigo (2009): "Contratos especiales", en: Revista Chilena de Derecho Privado (No 13), pp. 249-256.

(2011): "El régimen de los cumplimientos defectuosos en la compraventa", en: Revista Chilena de Derecho (Vol. 39, № 3), pp. 629-663.

(2013): "Contratos especiales", en: Revista Chilena de Derecho Privado ( No 21), pp. 355-361. 
(2015): "La conformidad de la cosa vendida: adecuación material" en: Revista de Derecho (Vol. 28, № 1), pp. 79-100.

Díez-Picazo y Ponce de León, Luis (2010): Fundamentos del Derecho Civil Patrimonial (Cizur Menor, Thomson Reuters), Tomo IV.

DucCI Claro, Carlos (1982): El arrendamiento de bienes raíces urbanos (Santiago de Chile, Imprenta Salesianos).

Galván Bernabeu, José Antonio (1998): "Conferencia Inaugural del II Congreso Chileno de Derecho Privado", en: $\operatorname{RDUCV}\left(\mathrm{N}^{\circ} 19\right)$.

Huber, Peter y Muluis, Alastair (2007): The CISG: A new textbook for students and practitioners (Munich, Sellier).

Lilleholt, Kåre et al. (2008): Principles of European Law Lease of Goods (PEL LG) (Munich, Sellier European Law Publishers).

Meza Barros, Ramón (2007): Manual de Derecho Civil, De las fuentes de las obligaciones (Santiago, Editorial Jurídica de Chile).

Morales Moreno, Antonio Manuel (2006): La modernización del Derecho de las obligaciones (Navarra, Thomson Civitas).

Musalem Blajtrach, Francisca (2015): La protección del acreedor frente a cumplimientos defectuosos en el Contrato de arrendamiento: Una idea para comenzar a hablar de conformidad en el derecho chileno (Santiago, Tesis, Universidad Diego Portales).

Orrego Acuña, Juan Andrés (2011): El contrato de arrendamiento (Santiago, Metropolitana).

Pizarro Wilson, Carlos (2008): "Hacia un sistema de remedios al incumplimiento contractual", en: Guzmán, Alejandro (Ed.), Estudios de Derecho Civil III (Santiago, Legal Publishing), pp. 395-402.

PothIER, Robert (1841): Tratado de la locación conducción (Traducc. Sociedad de amigos colaboradores, Barcelona, Imprenta y litografía de J. Roger).

Quintanilla PéRez, Álvaro (1977): La problemática del arrendamiento urbano (Valparaíso, Edeval).

Vidal Olivares, Álvaro (2007): "El incumplimiento de obligaciones con objeto fungible y los remedios del acreedor afectado. Una relectura de las disposiciones del 'Código Civil' sobre incumplimiento', en: Guzmán, Alejandro (Ed.), El Código Civil de Chile (1855-2005) (Santiago, LexisNexis).

(2009): "La noción de incumplimiento esencial en el 'Código Civil'", en: Revista de Derecho de la Pontificia Universidad Católica de Valparaíso (No 32), pp. 221-258. 
(2009a): "Cumplimiento e incumplimiento contractual en el "Código Civil". Una perspectiva más realista", en: Revista Chilena de Derecho (Vol. 34, No 1), pp. 41-59.

Vodanovic Haklicka, Antonio (1942): Curso de Derecho Civil. Basado en las explicaciones de los profesores de la Universidad de Chile Arturo Alessandri Rodríguez y Manuel Somarriva Undurraga (Santiago, Editorial Nascimento), Tomo IV. Fuentes de las obligaciones.

Zimmerman, Reinhard (1992): The Law of Obligations, Roman Foundations of the Civilian Tradition (Cape Town, Juta \& Co.).

\section{JURISPRUDENCIA CITADA}

Aguilera Parada con GSE Lining Technology Chile S.A. (2010): Corte de Apelaciones de Santiago, 6 de enero de 2010 (Cobro de rentas de arrendamiento), en: Legal Publishing CL/JUR/102/2010.

Alberto Borkert Hoffmann con Cristián Aliaga González (2015): Corte Suprema, 27 de octubre de 2015 (Terminación de contrato de arrendamiento), en: Legal Publishing CL/JUR/6464/2015.

Alejandra Victoria Cabrera Pacheco y Sucesión Cabrera Payá con SQM Nitratos S.A. (2003): Corte de Apelaciones de Santiago, 27 de marzo de 2003 (Terminación de contrato de arrendamiento), en: Legal Publishing $\mathrm{CL} / J U R / 2697 / 2003$.

Ávalos Vera, Catherine Rosalva con Antil Lepil, Rosalía (2014): Corte de Apelaciones de Santiago, 28 de marzo de 2014 (Terminación de contrato de arrendamiento, Indemnización de perjuicios), en: Legal Publishing $\mathrm{CL} / \mathrm{JUR} / 617 / 2014$.

Banco Falabella con Lidia del Carmen Heresmann Fuentes (2015): Corte de Apelaciones de Santiago, 16 de octubre de 2015 (Acción de precario), en: Legal Publishing CL/JUR/6257/2015.

Comercial e Inversiones Atlántida S.A. con Santander Asset Managment S.A. (2014): Corte Suprema, 17 de marzo de 2014 (Terminación de contrato de arrendamiento), en: Legal Publishing CL/JUR/466/2014.

Comercial Rapel S.A. con Comercializadora de Combustibles Cochilco Limitada (2016): Corte Suprema, 31 de mayo de 2016 (Terminación de contrato de arrendamiento), en: Legal Publishing CL/JUR/3616/2016.

Comercial y Servicios Chile Emprende Ltda. con Inmobiliaria Elissalde Candela Ltda. (2015): Corte Suprema, 13 de agosto de 2015 (Terminación de contrato de arrendamiento), en: CL/JUR/4597/2015. 
Francisco Leiva Carvajal con Mario Guerrero Avalos (2015): Corte Suprema, 26 de marzo de 2015 (término de contrato de arrendamiento y restitución del inmueble), en: Legal Publishing CL/JUR/1609/2015.

Glide Diversiones Limitada con Compañía de Inversiones y Desarrollo Sur S.A. (2007): Corte de Apelaciones de Santiago, 29 noviembre 2007 (arrendamiento, principio de buena fe contractual, responsabilidad precontractual), en: Legal Publishing CL/JUR/3963/2007.

Glide Diversiones Limitada con Compañía de Inversiones y Desarrollo Sur S.A. (2008): Corte Suprema, 19 de mayo de 2008 (Término de contrato de arrendamiento e indemnización de perjuicios), en: Legal Publishing CL/JUR/5837/2008.

Hugo Valderrama Castro con José Bustos Toledo y otra (2015): Corte Suprema, 27 de octubre de 2015 (Acción de precario), en: Legal Publishing CL/JUR/6448/2015.

Ideasupply Soc. Colectiva Civil y otra con Mauricio Cartes Agrícola E.I.R.L. (2013): Corte de Apelaciones de Santiago, 11 de octubre de 2013 (Término del contrato de arrendamiento), en: Legal Publishing CL/JUR/2266/2013.

Inmobiliaria Sandoval S.A. con Lidia Saavedra Sánchez (2015): Corte Suprema, 5 de noviembre de 2015 (Restitución de inmueble por extinción del derecho del arrendador), en: Legal Publishing CL/JUR/6735/2015.

Inmobiliaria Santo Stefano Ltda con Félix Valenzuela (1993): Corte de Apelaciones de Santiago, de 17 de agosto de 1993 (Terminación de contrato de arrendamiento), en: Legal Publishing CL/JUR/912/1993.

Juana Gloria Muñoz Moreira con José Muñoz Aguayo (2003): Corte Suprema, 29 de septiembre de 2003 (Terminación de contrato de arrendamiento e indemnización de perjuicios), en: Legal Publishing CL/JUR/3633/2003.

Martínez Cordero, Mónica contra Consejo de Defensa del Estado (2009): Corte Suprema, 28 de diciembre de 2009 (reclamo por monto de la expropiación), en: Legal Publishing CL/JUR/5382/2009.

Medina Conejeros, Mónica Trinidad con Aravena Arriagada, Nancy del Carmen (2008): Corte Suprema, 2 de julio de 2008 (Terminación de contrato de arrendamiento), en: Legal Publishing CL/JUR/2812/2008.

Osorio, Ramón contra Córdova Palma, Abel (1987): Corte de Apelaciones de Temuco, de 13 de abril de 1987 (Restitución por extinción del derecho del arrendador), en: Legal Publishing CL/JUR/105/1987.

Pagani con Rosemberg (1949): Corte de Apelaciones de Santiago, 31 de agosto de 1949 (juicios en que procede el saneamiento de la evicción), en: Revista de Derecho y Jurisprudencia, Tomo 47 (1950), II, Sección 2a , p. 1. 
Schaub Galbiati, Eric (1982): Corte de Apelaciones de Santiago, 31 de diciembre de 1982 (Reclamo de ilegalidad municipal, saneamiento de la evicción), en: Micro Juris MJJ6279.

Servicios Turísticos Globales S.A. contra Juan Ignacio López Donoso y Compañía Ltda. (2009): Corte de Apelaciones de Valparaíso, 30 de septiembre de 2009 (Terminación de contrato de arrendamiento), en: Legal Publishing CL/JUR/1632/2009.

Servicios Ultracorp Limitada con Carolina Bonomelli Olguín (2015): Corte Suprema, 9 de junio de 2015 (Terminación de contrato de arrendamiento), en: Legal Publishing CL/JUR/3218/2015.

Sociedad de enseñanza Perinatal y de Cuidados del Recién Nacido S.P.A. con Roberto Fresard Figueroa (2016): Corte Suprema, 6 de octubre de 2016 (Terminación de contrato de arrendamiento con indemnización de perjuicios), en: Legal Publishing CL/JUR/6925/2016.

Sociedad de Inversiones Santa Marta III S.A. con Comercializadora Rossetti Limitada (2014): Corte Suprema, 24 de diciembre de 2014 (Terminación de contrato de arrendamiento), en: Legal Publishing CL/JUR/9851/2014.

Sociedad Inmobiliaria Santa Isabel Limitada (2006): Corte de Apelaciones de Concepción, 14 de julio de 2006 (Terminación de contrato de arrendamiento), en: Legal Publishing CL/JUR/2183/2006. 